University of Nebraska - Lincoln

DigitalCommons@University of Nebraska - Lincoln

2002

\title{
A New Species of Enaphalodes Haldeman from Florida (Coleoptera: Cerambycidae) with Review of Genus, Synonymy, and Key to Species
}

\author{
Steven W. Lingafelter \\ Systematic Entomology Laboratory, Plant Sciences Institute Agriculture Research Service, U.S. \\ Department of Agriculture c/o National Museum of Natural History, MRC-168 Washington, D.C. 20560, \\ U.S.A.
}

John A. Chemsak

Essig Museum of Entomology 201 Wellman Hall University of California Berkeley, CA 94720, U.S.A.

Follow this and additional works at: https://digitalcommons.unl.edu/systentomologyusda

Part of the Entomology Commons

Lingafelter, Steven W. and Chemsak, John A., "A New Species of Enaphalodes Haldeman from Florida (Coleoptera: Cerambycidae) with Review of Genus, Synonymy, and Key to Species" (2002). USDA Systematic Entomology Laboratory. 18.

https://digitalcommons.unl.edu/systentomologyusda/18

This Article is brought to you for free and open access by the Entomology Collections, Miscellaneous at DigitalCommons@University of Nebraska - Lincoln. It has been accepted for inclusion in USDA Systematic Entomology Laboratory by an authorized administrator of DigitalCommons@University of Nebraska - Lincoln. 
The Coleopterists Bulletin, 56(4):569-581. 2002.

\title{
A New Species of Enaphalodes Haldeman from Florida (Coleoptera: Cerambycidae) With Review of Genus, SyNONYMY, AND KeY TO SPECIES
}

\author{
STEVEN W. Lingafelter \\ c/o National Museum of Natural History, MRC-168 \\ Washington, D.C. 20560, U.S.A. \\ AND \\ John A. ChemsaK \\ Essig Museum of Entomology \\ 201 Wellman Hall \\ University of California \\ Berkeley, CA 94720, U.S.A.
}

Systematic Entomology Laboratory, Plant Sciences Institute Agriculture Research Service, U.S. Department of Agriculture

\begin{abstract}
A new species of Enaphalodes, E. archboldi Lingafelter and Chemsak, is described from Archbold Research Station, Highlands County, Florida. This localized species has been confused with $A$. rufulus (Haldeman), a widespread species, which it resembles. Romaleum decipiens Bates is designated as a new synonym of E. atomarius (Drury). Romaleum cylindricum Knull is designated as a new synonym of E. cortiphagus (Craighead). Diagnoses, habitus photographs and drawings, and a key to the nine recognized species of Enaphalodes are provided.
\end{abstract}

The genus Enaphalodes (Coleoptera: Cerambycidae: Cerambycinae: Elaphidiini) (Fig. 3) contains nine species of moderate-sized woodboring beetles which occur primarily in the United States and Mexico, but with two species also occurring in Central America (Monné 1993; Monné and Giesbert 1993). Species in the genus are usually associated with Quercus (E. hispicornis [Linnaeus]; E. rufulus [Haldeman]; E. atomarius [Drury]; E. cortiphagus [Craighead]), but also use Salix (Enaphalodes taeniatus [LeConte]), Acer (E. rufulus [Haldeman]), Castanea, Celtis, Juglans, and Carya (E. atomarius [Drury]) (Linsley 1963). All species of Enaphalodes are nocturnal and strongly attracted to lights; adults emerge from hosts at night from April-October in the United States and do a little feeding on twigs and foliage. They aggregate on sapflows and can be collected with fermented solutions (Lingafelter and Horner 1993; Solomon 1995).

While curating the National Collection of Beetles of the Smithsonian Institution, the senior author discovered specimens of the new species of Enaphalodes mixed in with the common E. rufulus (Haldeman). Most specimens are from the Archbold Biological Station $\left(27^{\circ} 11^{\prime} \mathrm{N}, 81^{\circ} 21^{\prime} \mathrm{W}\right)$ in Highlands County, Florida. The region of the Archbold station is at the southern end of the Lake Wales Ridge, with communities of southern ridge sandhills and sand pine scrub containing many endemic plants and animals (Abrahamson et al. 1984; Deyrup 1990).

We review the species in Enaphalodes, designate two new synonyms, de- 
scribe the new species from Florida, and provide a detailed diagnostic key to identify all described species of Enaphalodes. Figures and diagnostic characters are provided. Acronyms used are as follows: NMNH (Smithsonian Institution, National Museum of Natural History); ABSC (Archbold Biological Station collection); FSCA (Florida State Collection of Arthropods); EMEC (Essig Museum of Entomology); MTEC (Montana State University Collection); PSUC (Frost Entomological Museum, Pennsylvania State University); CMNH (Bob Androw Collection/Carnegie Museum of Natural History); FMNH (Field Museum of Natural History); UCFC (University of Central Florida); JCPC (Jim Cope private collection); RMPC (Roy Morris private collection); JWPC (Jim Wappes private collection); RTPC (Robert Turnbow private collection); and DHPC (Dan Heffern private collection).

\section{Genus Enaphalodes Haldeman*}

Enaphalodes Haldeman 1847: 151. Type species: Cerambyx pulverulentus DeGeer 1775 (= Cerambyx atomarius Drury 1773). Designated by Linsley 1963:63.

Romaleum White 1855: 309. Type species: Romaleum operarium White 1855 (= Cerambyx hispicornis Linnaeus 1767). By monotypy.

Hypermallus Lacordaire 1869: 302. Type species: Cerambyx pulverulentus DeGeer 1775 (= Cerambyx atomarius Drury 1773). Original designation.

Thersalus Pascoe 1865: 372. Type species: Phacodes bispinosus Pascoe 1863 (= Cerambyx atomarius Drury 1773). By monotypy.

*See Linsley (1963) for additional references.

Diagnosis. Enaphalodes is most closely related to Romulus, Orwellion, Eustromula, Gymnospyra, and Parelaphidion (Lingafelter 1998). It differs from Romulus by having more conspicuous pubescence on the elytra and pronotum, moderately spinose elytral apices in most species (truncate to dentiform in Romulus), more pronounced antennal spination (weak in Romulus), and smaller size of most specimens. More careful study of Romulus may support its inclusion within Enaphalodes. Enaphalodes, Orwellion, and Eustromula are unique among North American elaphidiines in having the scutellum acutely pointed posteriorly. Enaphalodes differs from Orwellion by lacking differentiated dense, white pubescence posterior to the upper eye lobes (present in Orwellion). The very short antennomeres of Eustromula (three through five approximately length of pronotum) will differentiate it from Enaphalodes (third through fourth longer than pronotum). Enaphalodes differs from Parelaphidion by its larger size, by having linear (or very weakly, gradually enlarged) metafemora (gradually enlarged in Parelaphidion), and pronotum inflated at middle and about as wide as base of elytra (not as widely expanded at middle in Parelaphidion). The length of antennomere three is about two-thirds the length of pronotum in Enaphalodes, which distinguishes it from most Anelaphus and Gymnospyra species (which have antennomere three about half the length of pronotum). Most Anelaphus species have the elytra truncate or dentiform, while Enaphalodes usually have elytral apices moderately to strongly bispinose. Further, Enaphalodes are considerably larger than all Anelaphus.

Key Characters of Enaphalodes. Moderate size, most specimens greater than $20 \mathrm{~mm}$ long and $8 \mathrm{~mm}$ wide; elytra and pronotum usually covered with dense connected patches of white or yellowish pubescence (uniform in a few 
species); females with an additional dense coating of short, erect hairs; elytra rarely with sparse pubescence; integument reddish to dark brown; ommatidial facets large; antennomere three of males and most females about two-thirds length of pronotum; mesal antennal spines present; pronotum broadly rounded and inflated, sides at middle projecting to width of base of elytra in males and nearly so in females; prosternal process expanded apically, nearly closing procoxal cavities posteriorly; procoxal cavities closed laterally; pronotum with calli and small impunctate regions; metepisternum very broad anteriorly, strongly narrowing posteriorly; lateral mesosternal projections into mesocoxae absent; femoral apices rounded; metafemoral shape linear or only weakly, gradually enlarged.

\section{Enaphalodes archboldi Lingafelter and Chemsak, new species}

Figs. 1-2, 3f, 4b, 5a

Description. Form moderate to large sized, 21-30 mm; integument uniformly reddishbrown, pronotum slightly darker than rest of body. Head densely clothed with short, fulvous, appressed pubescence, most dense around eye and on vertex and frons; pubescence sparse at middle of posterior of head; interantennal impression weak; antennal tubercle not pronounced; antenna of female not attaining elytral apex; antenna of male extending beyond elytral apex by three antennomeres; last antennomere of female subequal in length to penultimate antennomere; last antennomere of male nearly 1.5 times length of penultimate antennomere; antennomere four of female shorter than antennomere five; antennomere four of male longer than that of female, but shorter than antennomere five; antennal spines stronger in females, with antennomeres 3-9 having apicalmesad spines (ninth very small); in males, antennomeres 3-7 have apical-mesad spines (sometimes seventh and eighth antennomere just dentiform apicomesally); antenna fringed mesally with long fulvous to translucent pubescence (less conspicuous in males). Pronotum broader than long (broader in males than females) with dense fulvous, appressed hairs present and abundant (male with sparser hairs than female); pronotum of female inflated and widened, at middle slightly less than width of elytral base; pronotum of male larger and wider, at middle as wide as elytral base; pronotum in female with two small, circular calli anterior of middle and a small linear callus posterior to middle on midline; pronotum of male not as densely pubescent and with three longitudinal linear glabrous regions posteriorly and with denser pubescence in two short arcuate transverse bands at region where small circular calli are on female. Elytron with abundant, dense, fulvous, appressed and erect to suberect hairs (female with erect hairs more abundant than male); elytral pubescence uniform, without patches, obscuring elytral surface; elytral spines approximately equal in length and slightly convergent; the region between them moderately arcuate. Scutellum weakly acute posteriorly and with very dense, fulvous pubescence. Legs short, hind femur not extending beyond apical fourth of elytra; pubescence of femora white; elsewhere, pubescence of legs fulvous to translucent. Abdomen with ventral pubescence white, showing obvious color difference between dorsum and ventrum when viewed from lateral perspective; last ventral sternite of female with a very shallow notch at apex.

Comments. Enaphalodes archboldi is most similar to E. rufulus (Haldeman) and E. hispicornis (Linnaeus), from which it differs consistently in the denser appressed, uniform, conspicuous, and unmottled pubescence of the elytra (Figs. $1-2,3 \mathrm{f})$. This appressed pubescence is interspersed with longer erect hairs which are also uniformly distributed (Fig. 5a). In E. rufulus, the appressed pubescence is fulvous, but is not uniform, presenting a patchy appearance, and erect or suberect hairs are lacking (Figs. 3g, 5b). In E. hispicornis the pubescence is also uniform, but is not as dense, is not fulvous, and is not conspicuous (Figs. 3d, 5c). The integument of E. archboldi, like most E. rufulus, is 


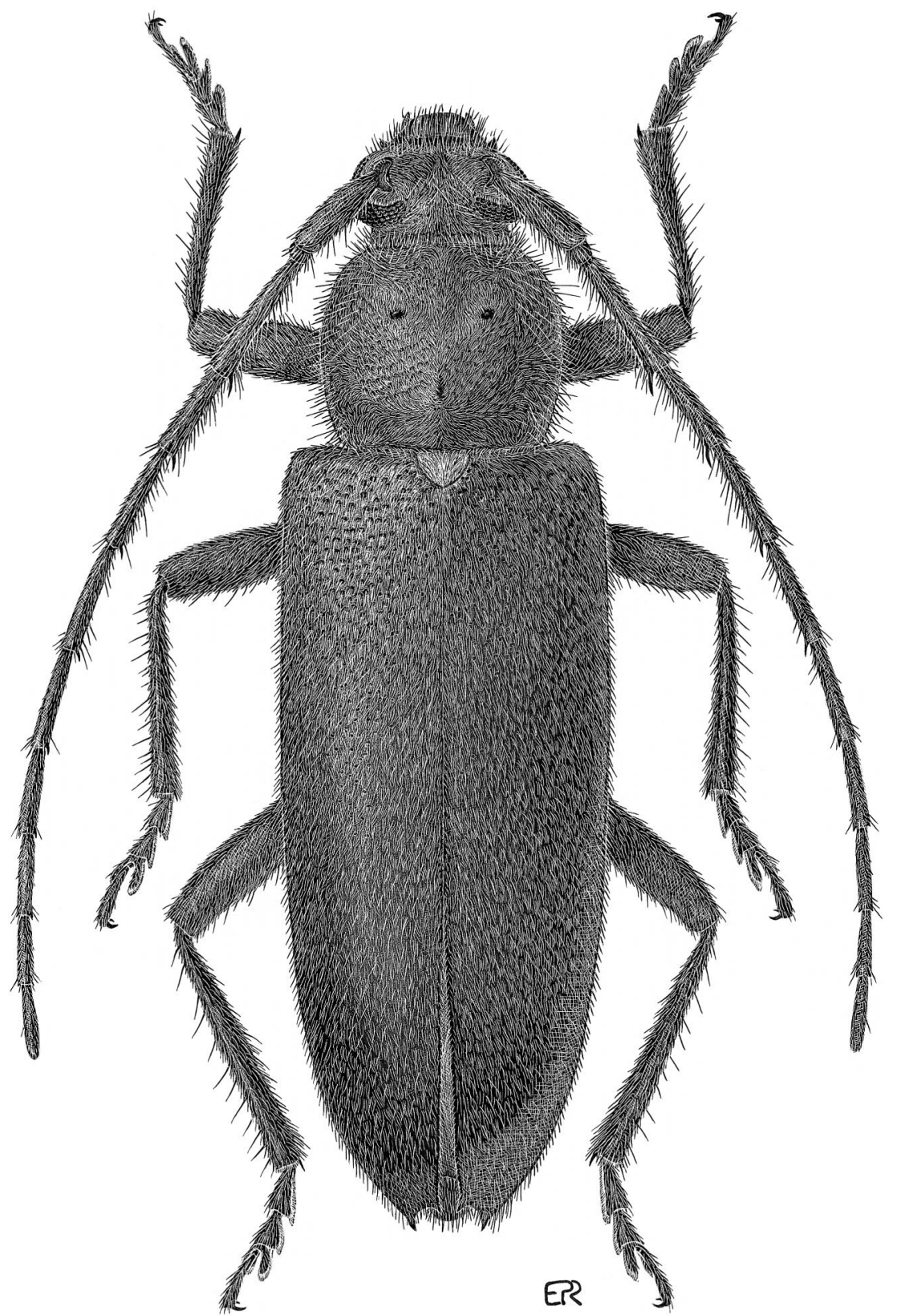

Fig. 1. Enaphalodes archboldi Lingafelter and Chemsak, new species, female dorsal view. 
reddish, while in E. hispicornis, it is dark brown. The elytral apical spines are shorter and slightly convergent in $E$. archboldi with the region between them arcuate as compared to E. rufulus which has parallel spines which are usually longer and the region between them is not or slightly arcuate. The last abdominal sternite of females has a deep notch at apex in E. archboldi (Fig. 4b), but is more shallow in E. rufulus (Fig. 4f) and deeper in E. hispicornis (Fig. 4d). Ventral pubescence is white on E. archboldi (Fig. 5a) but mostly fulvous on E. rufulus (Fig. 5b) and translucent on E. hispicornis (Fig. 5c).

Biology. Most specimens were collected at lights at Archbold Biological Station $\left(27^{\circ} 11^{\prime} \mathrm{N}, 81^{\circ} 21^{\prime} \mathrm{W}\right)$ in Highlands County, Florida by W. Rosenberg and L. L. Lampert, Jr. in August and September, in the 1970's. There apparently is a strong sex bias toward females (or females are disproportionately attracted to lights) because, of the 46 specimens known, 41 are females and only 5 are males. Other Enaphalodes species are highly attracted to lights, to dead wood at night (especially Quercus spp.), to sap flows, and to bait solutions of fermenting brown sugar or other concoctions. The biology of the closely-related Red Oak Borer, E. rufulus, was reviewed by Solomon (1995): Adults emerge in early summer and may be active until early fall. Adults are attracted to sap flows, but otherwise do not eat leaves or twigs. After mating, females will lay an average of 200 eggs scattered in bark crevices or elsewhere on host trees. Larvae will bore directly into the phloem and tunnel until the second spring when they pupate. Pupation lasts about three weeks and new adults will emerge in the early summer of the second year. In the northern U.S., most beetles emerge in odd numbered years, while in the southern U.S., almost as many emerge in even numbered years as in odd.

There are six species of oak in the Archbold Biological Station environs, of which one, the shrubby Archbold Oak, Quercus inopina Ashe, is probably endemic (Abrahamson et al. 1984; Johnson and Abrahamson 1982). It is almost certain that Quercus is the host genus of E. archboldi, based on knowledge of closely related species and scarcity of other genera of potential hosts (such as Salix and Acer) with which Enaphalodes have been associated (M. Deyrup, pers. comm.). There is a possibility that Quercus inopina Ashe is the host species of Enaphalodes archboldi based on the similarly restricted distributions of both species.

Etymology. This species name is a latin genitive patronym in honor of Mr. Richard Archbold, deceased, an enthusiastic naturalist and philanthropist who established the Archbold Biological Station and thus preserved many endemic species.

Type Data. Because relatively few males have been collected, we designate a specimen of the more common female sex as holotype. Most specimens were collected at Archbold Biological Station in Highlands County, Florida. We have abbreviated this locality as ABS for space considerations. The acronym in parentheses following locality data indicates the institution at which the specimen is deposited. Holotype, Female, Florida: Highlands Co. Archbold Biological Station [hereafter, ABS]; September 17, 1976, William Rosenberg, Collector (NMNH). Allotype, Male, ABS; September 19, 1976, William Rosenberg, Collector (NMNH). Paratypes: ABS; September 17, 1976, William Rosenberg, Collector (1, NMNH); same but September 22 (1, NMNH); same but September 20 (1, NMNH); same but September 16 (1, NMNH); same but September 15, 1975 (1, NMNH); same but September 24, 1978 (1, NMNH); same but August 24, 1978 (1, NMNH); Florida: Daytona Beach, 1959, W. Rosenberg Collection [data suspect] (1, DHPC); ABS, August 22, 1976, Wil- 


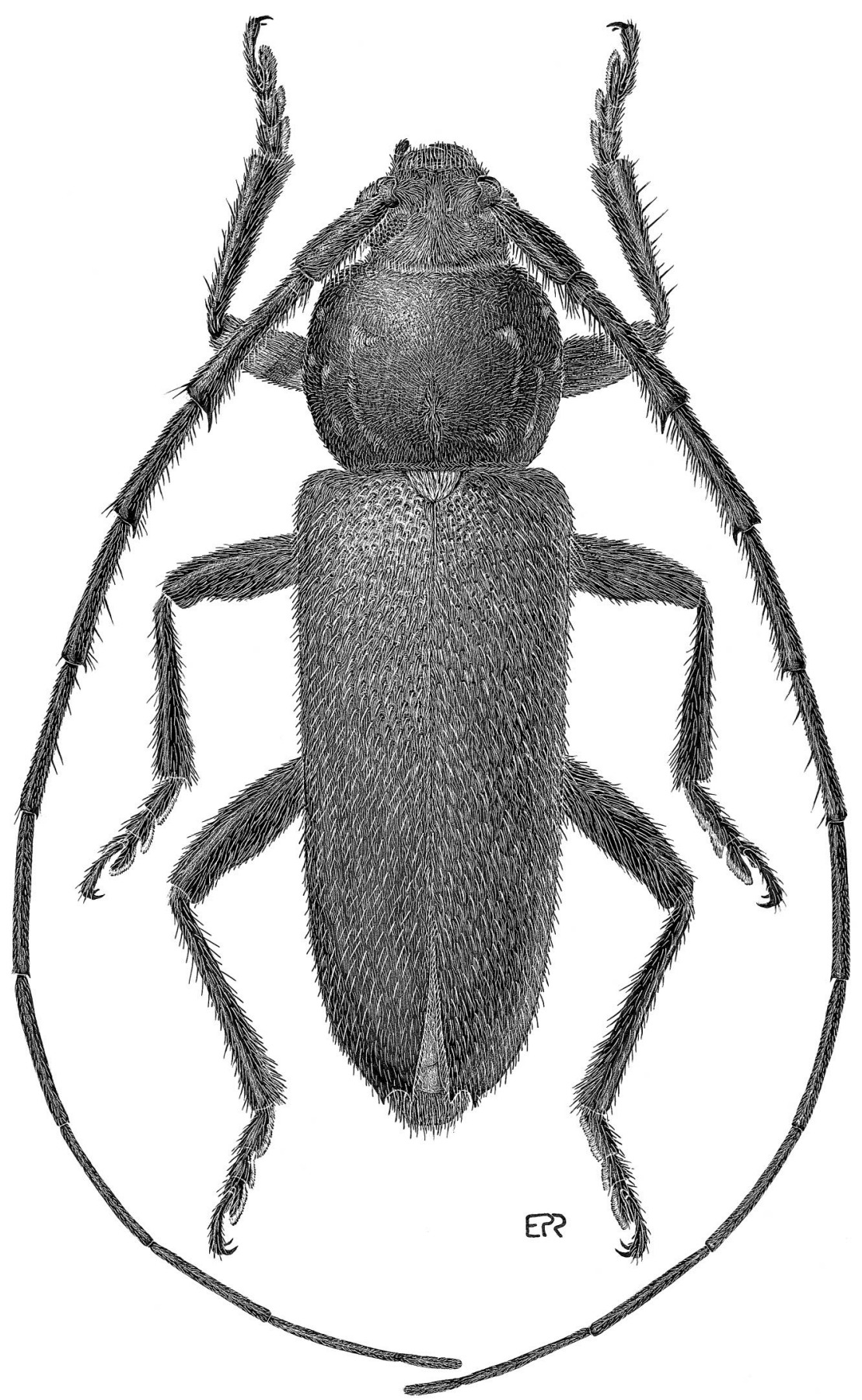

Fig. 2. Enaphalodes archboldi Lingafelter and Chemsak, new species, male dorsal view. 


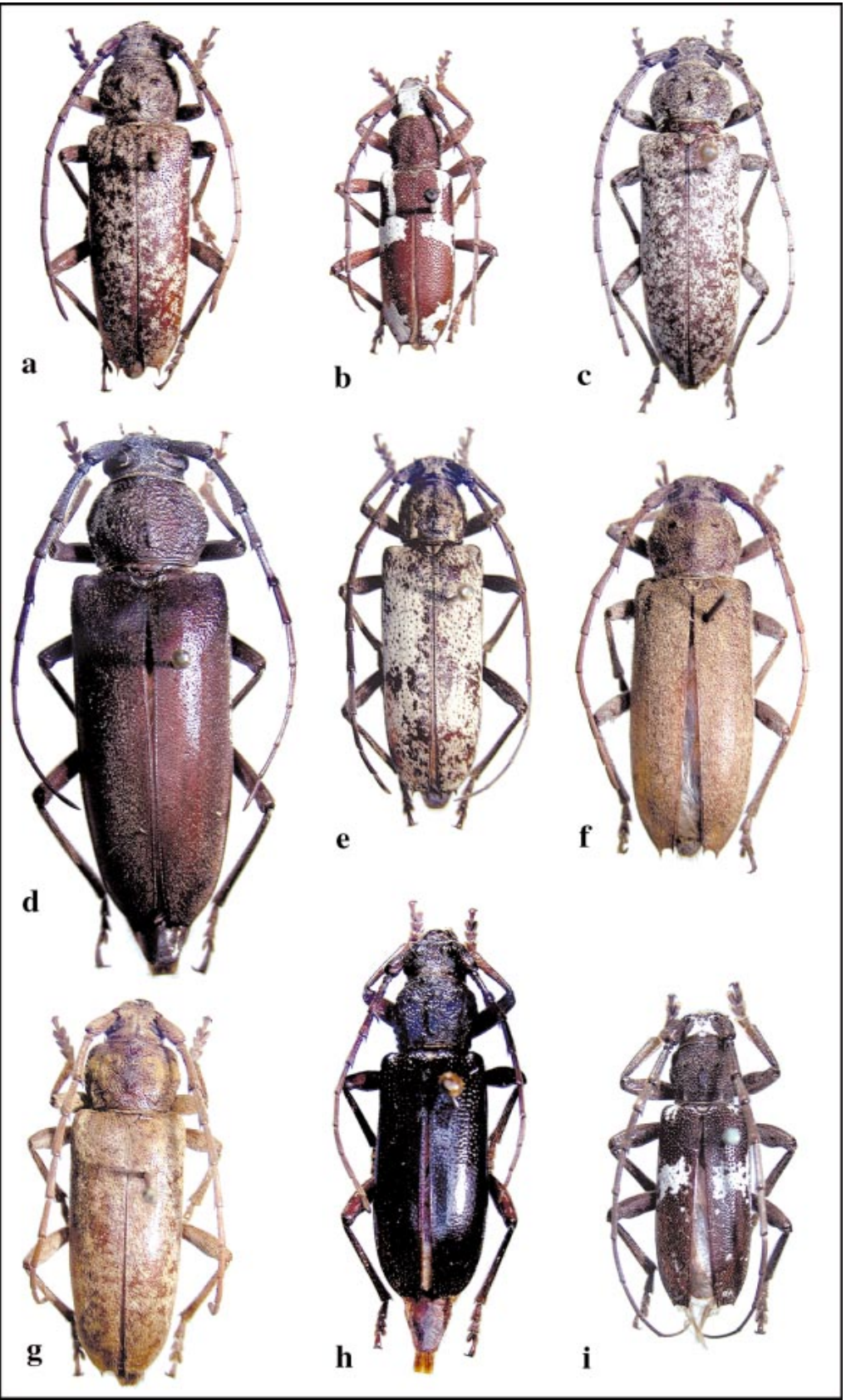

Fig. 3. Enaphalodes species, all 1.5 times natural size. a) E. atomarius (Drury) (female); b) E. coronatus (White) (female); c) E. cortiphagus (Craighead) (female); d) E. hispicornis (Linnaeus) (female); e) E. niveitectus (Schaeffer) (female); f) E. archboldi Lingafelter and Chemsak (female); g) E. rufulus (Haldeman) (female); h) E. seminitidus (Horn) (female); i) E. taeniatus (LeConte) (male). 

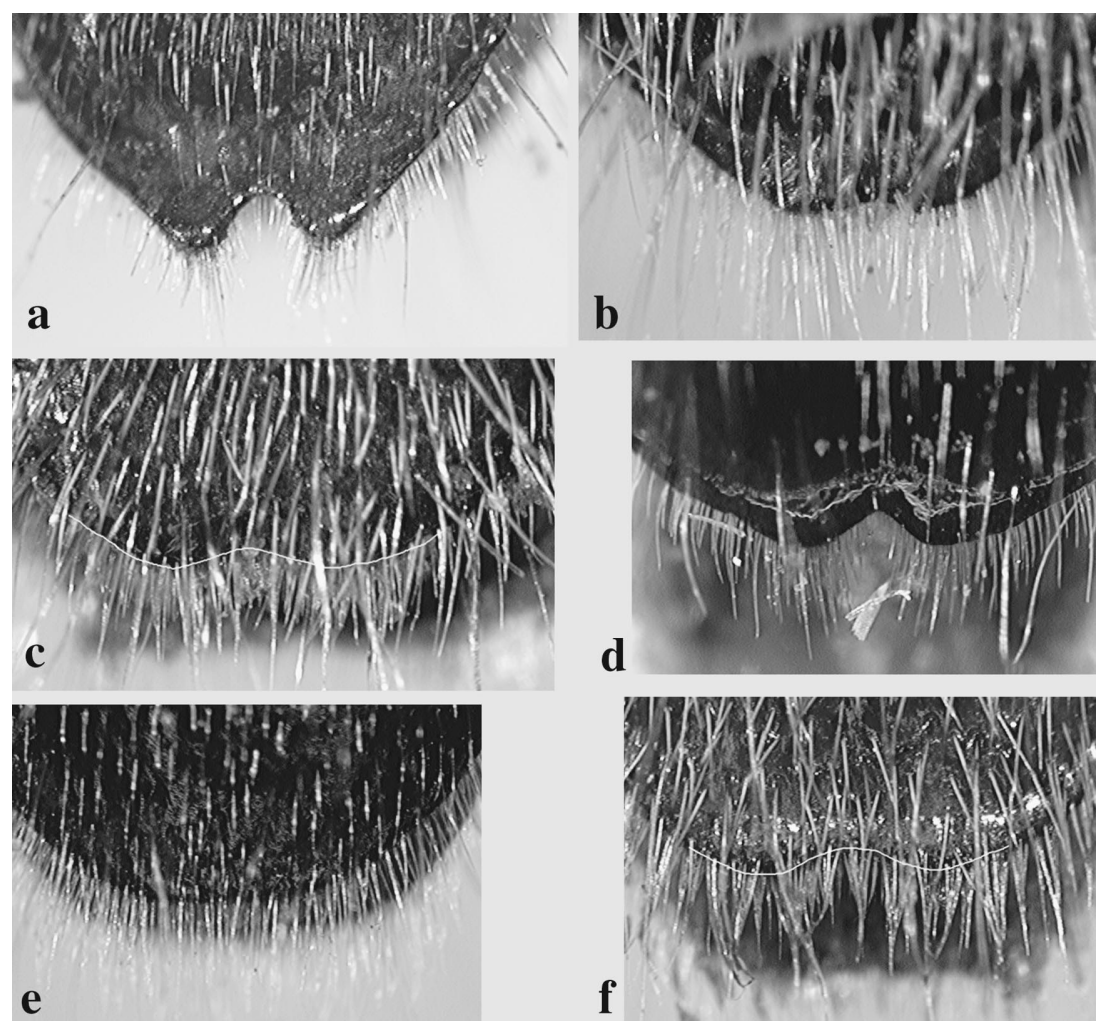

Fig. 4. Terminal ventral sternite apex of females. a) Enaphalodes atomarius (Drury); b) E. archboldi Lingafelter and Chemsak; c) E. cortiphagus (Craighead); d) E. hispicornis (Linnaeus); e) E. niveitectus (Schaeffer); f) E. rufulus (Haldeman).

liam Rosenberg, Collector (1, EMEC); ABS, Sept. 16, 1976, L. L. Lampert, Jr., UV light (1, FSCA); ABS, Sept. 11, 1975, L. L. Lampert, Jr., UV light (1, FSCA); ABS, Sept. 9, 1975, L. L. Lampert, Jr., UV light (4, FSCA); ABS, Sept. 19, 1975, L. L. Lampert, Jr., UV light (1, FSCA); ABS, Sept. 17, 1976, L. L. Lampert, Jr., UV light (1, FSCA); ABS, Sept. 10, 1981, L. L. Lampert, Jr., UV light (1, FSCA); ABS, Sept. 29, 1980, L. L. Lampert, Jr., UV light (1, FSCA); ABS, Sept. 25, 1981, L. L. Lampert, Jr., UV light (1, FSCA); ABS, Sept. 14, 1979, L. L. Lampert, Jr., UV light (1, FSCA); ABS, Sept. 28, 1980, L. L. Lampert, Jr., UV light (1, FSCA); ABS, September 16, 1976, U.V. light (1, JCPC); ABS, 23 August 1975, at lights, W. Sutter (1, MTEC); ABS, 5 mi. S. Lake Placid, August 24, 1965, at light, W. Sutter (1, MTEC); ABS, 24-28 September, 1978, N. M. Downie (5, FMNH); same but September 25, 1980 (1, FMNH); Florida: Polk Co., Lake Streety [mispelled "Streaty"], August 10, 1938, Hubbell and Friduf. (1, FMNH); Florida, Pinellas Co., August 17, 1938, Hubbell and Friduf. (1, FMNH); Florida: Marion Co., Ocala National Forest, fs. Road 88, July 23, 1999, Morris/Wappes (1, RMPC); ABS, 9 April 1975 [month/date probably reversed when label was reproduced on specimen], UV light, Lester L. Lampert, coll. (1, CMNH); same but September 4, 1975 (1, 

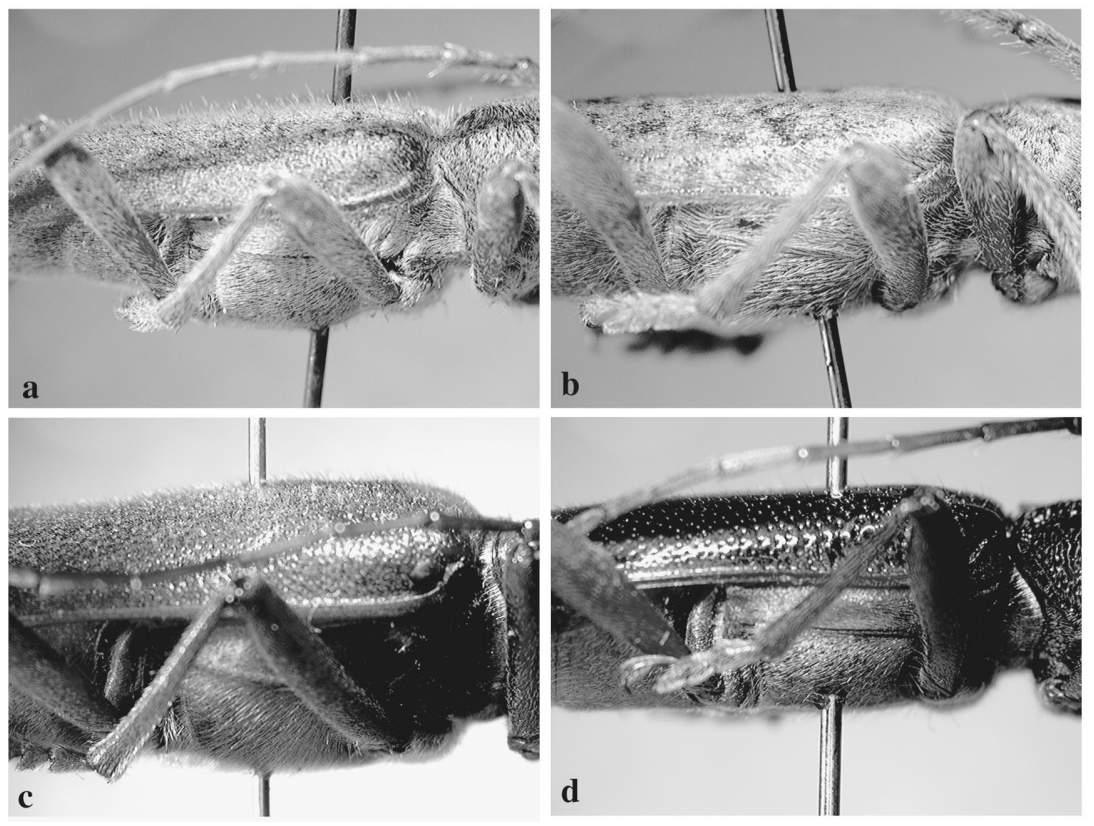

Fig. 5. Lateral view of abdomen and elytron of females. a) Enaphalodes archboldi Lingafelter and Chemsak; b) Enaphalodes rufulus (Haldeman); c) Enaphalodes hispicornis (Linnaeus); d) Enaphalodes seminitidus (Horn).

CMNH); Florida, Orange Co., Rk Spr Rn St Res, September 17, 1974, S.Pine/ oak scrub, Malaise Trap, J. C. Longhurst, S. M. Fullerton (1, CFUC); Orange County, Florida, UCF Orlando, June 25, 1994, Sand Pine Rosemary Scrub, UV Light Trap, S. M. Fullerton, Collector (1, CFUC); Lake Placid, 8 mi. S. ABS, 6 September, 1982, M. Deyrup (1, ABSC); ABS, Lake Placid, Sept. 21, 1992, Mueller (1, ABSC); ABS, September 26, 1979; L. L. Lampert, Jr. (1, ABSC donated to NMNH); same but September 16, 1976 at U.V. light (1, ABSC donated to NMNH); ABS, R. J. Nagal, 1 September, 1964 (1, ABSC donated to EMEC); ABS, 18 September 1983, M. Deyrup (1, ABSC donated to EMEC).

\section{Review of Species of Enaphalodes}

There are presently nine recognized species of Enaphalodes and all but two have their primary distributions in the United States (Monné 1993; Monné and Giesbert 1993). Enaphalodes atomarius (Drury) (Fig. 3a) occurs throughout eastern and central North America into Texas, and south through Mexico and Honduras; E. coronatus (White) (Fig. 3b) in Mexico through Costa Rica; E. cortiphagus (Craighead) (Fig. 3c) in the northeastern United States west to Arizona; E. hispicornis (Linnaeus) (Fig. 3d) throughout the United States, especially the southern half and northern Mexico; E. niveitectus (Schaeffer) (Fig. $3 e)$ in the southwestern United States, especially Arizona, and northern Mexico; E. archboldi Lingafelter and Chemsak (Figs. 1, 2, 3f) in the highlands of south-central Florida, especially the area of the southern Lake Wales Ridge 
around Archbold Biological Station in Highlands County; E. rufulus (Haldeman) (Fig. 3g) in the eastern United States and west to western Texas; E. seminitidus (Horn) (Fig. 3h) in the southwestern United States, especially Arizona and California; and E. taeniatus (LeConte) (Fig. 3i) in the southwestern United States, especially southern Texas, and northeast Mexico.

Romaleum decipiens Bates 1884 is a New Synonym of Enaphalodes atomarius (Drury 1773). Examination of the holotype has revealed that there are no characters to distinguish it from the variable E. atomarius (Drury). Further, Chemsak et al. (1980) demonstrated the distribution of A. atomarius into Zamorano, Honduras, thus enveloping the type locality of Romaleum decipiens Bates (Paso del Macho, Veracruz, Mexico) well within the revised range of $E$. atomarius (Drury). Romaleum cylindricum Knull 1927 is a New Synonym of Enaphalodes cortiphagus (Craighead 1923). Examples of both taxa from the type localities has revealed that the only differences are that the Arizona populations have slightly brighter white pubescence and females have a slightly deeper notch (still quite shallow) on the terminal abdominal sternite apex than do the females from Pennsylvania. Because these are both variable characters and no definitive invariable characters have been found to separate the two, we synonymize E. cylindricus Knull.

\section{Key to Species of Enaphalodes}

1 Elytra with dense appressed hairs abundant, and conspicuous (Figs. 3a-g, i, 5a-c)

$1^{\prime}$ Elytra without appressed hairs and only sparse translucent hairs at apex of elytra and in elytral punctures (Figs. 3h, 5d). This species also has weak elytral spines (outer spine often just slightly protuberant); last ventral sternite rounded at apex in females, and with mostly translucent hairs at middle of metasternum and white hairs at sides of metasternum. Length, 24-29 $\mathrm{mm}$

E. seminitidus (Horn)

2 Elytra with one to three well-defined areas of dense, appressed pubescence, otherwise ground color not obscured by pubescence (Fig. 3b, i) ___ 3

$2^{\prime}$ Elytra with pubescence otherwise: either uniform, without patches of dense, appressed pubescence, or with numerous interconnecting, poorly defined appressed patches, giving a mottled appearance (Fig. 3a, c-g) _. 4

3 Vertex and frons with a very dense, bright white patch of pubescence between the eyes, becoming diffuse and less distinctive toward clypeal margin and on vertex above eyes (Fig. 3i); elytra with one transverse patch of white pubescence anterior to middle and a patch on humeri (Fig. 3i); apicolateral elytral spine moderate in most specimens; last ventral sternite of female rounded at apex (as in Fig. 4e). Length, 19-25 mm

E. taeniatus (LeConte)

3' Vertex and frons with a very dense, bright white patch of pubescence between and above eyes, extending to clypeal margin (Fig. 3b); elytra with two well-defined patches of bright white pubescence at apex and around epipleura (Fig. 3b); apicolateral elytral spines usually strong; last ventral sternite in females rounded at apex (as in Fig. 4e). Length, 14-22 mm -.. 
4 Elytra not appearing mottled (Figs. 1-2, 3d, f); without patches of appressed pubescence; erect, suberect, and appressed pubescence uniform in density and distribution

4' Elytra appearing mottled (Fig. 3a, c, e, g); with patches of appressed pubescence; erect, suberect, or appressed pubescence not uniform in density and distribution

5 Large species, with pubescence inconspicuous and not heavily obscuring elytral surface (Fig. 3d); ventral pubescence mostly translucent with slight golden sheen (Fig. 5c); last ventral sternite of females with a deep notch at apex (Fig. 4d). Length, 27-40 mm E. hispicornis (Linnaeus)

5 ' Moderate to large species with conspicuous uniform appressed fulvous pubescence that densely covers elytral surface (Figs. 1-2, 3f); ventral pubescence mostly white and not translucent, distinctly different color from dorsal pubescence (Fig. 5a); last ventral sternite of females with a very shallow notch at apex (Fig. 4b). Length, 21-30 mm

E. archboldi Lingafelter and Chemsak

6 Sides of pronotum at middle nearly as wide as base of elytra in males (Fig. 3a, c, g); elytra light to dark brown with appressed pubescence extensive but not bright white and not contrasting as intensely with elytral ground color (appearing diffusely mottled) (Fig. 3a, c, g); last ventral sternite of female weakly or deeply notched at apex (Fig. 4a, c, f) _..__._. 7

6 ' Pronotum with slight widening anterior to middle, but much narrower at widest point than base of elytra (Fig. 3e); elytra dark brown with appressed pubescence extensive and conspicuously bright white (distinctly mottled) (Fig. 3e); last ventral sternite of female rounded at apex (Fig. 4e). Length, 22-27 mm

E. niveitectus (Schaeffer)

7 Elytra with white or off-white appressed pubescence and light to dark brown ground color (rarely reddish-brown) (Fig. 3a, c); longer erect to suberect setae present (as in Fig. 5a); last abdominal sternite of females with deep or shallow notch at apex

7' Elytra with fulvous appressed pubescence and reddish or light brown ground color (Fig. 3g); without erect setae (except a few along suture and apical third) (Fig. 5b); last abdominal sternite of females with very shallow notch at apex (Fig. 4f). Length, 14-26 mm E. rufulus (Haldeman)

8 Pubescence of metasternum primarily translucent (Fig. 5b); last abdominal sternite of female deeply notched at apex (Fig. 4a); elytra with diffuse patches of off-white pubescence (Fig. 3a). Length, 19-29 mm

E. atomarius (Drury)

$8^{\prime}$ Pubescence of metasternum primarily white and not translucent; last abdominal sternite of female with very shallow notch at apex (Fig. 4c); elytra with diffuse patches of white or off-white pubescence (Fig. 3c). Length, $16-27 \mathrm{~mm}$ E. cortiphagus (Craighead)

\section{Acknowledgments}

We sincerely thank Mark Deyrup (ABSC), Mike Thomas (FSCA), Mike Ivie (MTEC), K. C. Kim and John Grehan (PSUC), Bob Androw (CMNH), 
Roy Morris (RMPC, Lakeland, Florida), Jim Cope (JCPC, San Jose, California), Philip Parrillo and Al Newton (FMNH), Jim Wappes (JWPC, Bulverde, Texas), Robert Turnbow (RTPC, Ft. Rucker, Alabama), S. Fullerton (and Paul Skelley who forwarded specimens) (UCFC), and Dan Heffern (DHPC, Houston, Texas) for examining their collections and/or sending additional specimens for inclusion in this study. Mark Deyrup generously donated some specimens of the ABSC collection to USNM and EMEC. Elisabeth Roberts (SEL, PSI, ARS, USDA) prepared the excellent scratchboard illustrations of the new species. Norman Woodley (SEL, PSI, ARS, USDA), Warren Steiner (NMNH), and Dan Heffern (Houston, Texas) tested and provided comments on the key. F. Christian Thompson, Allen Norrbom, Dan Heffern and an anonymous reviewer provided helpful suggestions.

\section{Literature Cited}

Abrahamson, W. G., A. F. Johnson, J. N. Layne, and P. A. Peroni. 1984. Vegetation of the Archbold Biological Station, Florida: an example of the southern Lake Wales Ridge. Florida Scientist 47(4):209-250.

Bates, H. W. 1884. Biologia Centrali-Americana, Insecta, Coleoptera, suppl. to Longicornia, London 5:225-248.

Chemsak, J. A., E. G. Linsley, and J. V. Mankins. 1980. Records of some Cerambycidae from Honduras (Coleoptera). Pan-Pacific Entomologist 56:26-37.

Craighead, F. C. 1923. North American cerambycid-larvae. Bulletin of the Canadian Department of Agriculture (n. s.) 27:1-239, 44 pls.

Deyrup, M. 1990. Arthropod footprints in the sands of time [Symposium on origin of southeast Arthropod fauna]. Florida Entomologist 73:529-538.

Haldeman, S. S. 1847. Descriptions of several new species and one new genus of insects. Proceedings of the Academy of Natural Sciences of Philadelphia 3:149-151.

Johnson, A. F., and W. G. Abrahamson. 1982. Quercus inopina: a species to be recognized from south-central Florida. Bulletin of the Torrey Botanical Club, Torreya $109: 392-395$.

Knull, J. F. 1927. Descriptions of Coleoptera with Notes (Buprestidae and Cerambycidae). Entomological News 38:115-118.

Lacordaire, J. T. 1869. Genera des coléoptères ou exposé méthodique et critique de tous les genres proposés jusqu'ici dans cet ordre d'insectes, Paris, Librairie Encyclopédique de Roret 8:1-552.

Lingafelter, S. W. 1998. The Genera of Elaphidiini Thomson (Coleoptera: Cerambycidae). Memoirs of the Entomological Society of Washington, No. 20:1-118.

Lingafelter, S. W., and N. V. Horner. 1993. The Cerambycidae of North-central Texas. Coleopterist's Bulletin 47:159-191.

Linsley, E. G. 1963. The Cerambycidae of North America. Part IV. Tribes Elaphidionini through Rhinotragini. University of California Publications in Entomology vol. 21:1-165.

Monné, M. A., and E. F. Giesbert. 1993. Checklist of the Cerambycidae and Disteniidae (Coleoptera) of the Western Hemisphere. Wolfsgarden Books, Burbank, California: $410 \mathrm{pp}$.

Monné, M. A. 1993. Catalogue of the Cerambycidae (Coleoptera) of the Western Hemisphere, Part IV. Publicação Sociedade Brasileira de Entomologia, São Paulo. 129 pp.

Pascoe, F. P. 1865. A second series of descriptions of new Australian Longicornia. Journal of Entomology 2(12):352-374.

Solomon, J. D. 1995. Guide to insect borers of North American broadleaf trees and 
shrubs. Agricultural Handbook No. 706. Washington, D.C.: United States Department of Agriculture, Forest Service. 735 pp.

White, A. 1855. Catalogue of the coleopterous insects in the collection of the British Museum. Longicornia 2. London 8:175-412, Plates 5-10.

(Received 27 February 2001; accepted 5 July 2001) 